\title{
Host-parasite and phylogenetic relationships of Myxobolus filamentum sp. n. (Myxozoa: Myxosporea), a parasite of Brycon orthotaenia (Characiformes: Bryconidae) in Brazil
}

\author{
Juliana Naldoni ${ }^{1}$, Suellen A. Zatti ${ }^{1}$, Kassia R.H. Capodifoglio ${ }^{2}$, Tiago Milanin ${ }^{1}$, Antônio A.M. Maia ${ }^{2}$, Marcia R.M. \\ Silva $^{2}$ and Edson A. Adriano ${ }^{1,3}$ \\ ${ }^{1}$ Animal Biology Department, Institute of Biology, University of Campinas, São Paulo, Brazil; \\ ${ }^{2}$ Veterinary Medicine Department, College of Animal Science and Food Engineering, São Paulo University, São Paulo, Brazil; \\ ${ }^{3}$ Biology Science Department, Federal University of São Paulo, São Paulo, Brazil
}

\begin{abstract}
Myxobolus filamentum sp. n. was found infecting gill filaments of three of 39 Brycon orthotaenia Günther specimens examined (8\%), which were taken from the river São Francisco in Minas Gerais state, Brazil. Plasmodia of the parasite were white and long, measuring $5 \mathrm{~mm}$ in lenght. Mature spores of M. filamentum sp. $\mathrm{n}$. were oval from the frontal view and biconvex from the lateral view, measuring 7.5-9.7 $\mu \mathrm{m}(9.0 \pm 0.3 \mu \mathrm{m})$ in length and 5.2-7.3 $\mu \mathrm{m}(6.2 \pm 0.4 \mu \mathrm{m})$ in width. The polar capsules were elongated and equal in size, measuring 3.8-5.5 $\mu \mathrm{m}(4.7 \pm 0.3 \mu \mathrm{m})$ in length and 1.3-2.2 $\mu \mathrm{m}(1.7 \pm 0.1 \mu \mathrm{m})$ in width. The development of the parasite led to compression of the adjacent tissues and inflammatory infiltrate with granulocytic cells. Ultrastructural observation revealed that the plasmodia were delimited by two membranes, which had numerous and extensive pinocytotic channels extending into the wide ectoplasm zone. The plasmodial wall exhibited abundant villi-like projections and a thin layer of granular material prevented direct contact between the plasmodial wall and the host tissue. Phylogenetic analysis, based on 18S rDNA, showed M. filamentum sp. n. as a sister species of Myxobolus oliveirai Milanin, Eiras, Arana, Maia, Alves, Silva, Carriero, Ceccarelli et Adriano, 2010, a parasite of other fish species of the genus Brycon Müller et Troschel from South America.
\end{abstract}

Keywords: taxonomy, 18S rRNA, ultrastructure, granulocytic cells, freshwater fish, Neotropical Region

Myxosporeans are among the most important pathogens for both wild and farmed fish. Most species use fish as host, although a small number have been described infecting amphibians, reptiles, birds and mammals (Eiras et al. 2005, Prunescu et al. 2007, Bartholomew et al. 2008). The genus Myxobolus Bütschli, 1882 is the most speciouse group within the myxozoans, with more than 850 species described (Eiras et al. 2014). So far, 37 Myxobolus species have been described infecting fish species in South America (Eiras et al. 2005, 2014) and nine species have been reported for fish of the family Bryconidae (Characiformes) (Azevedo et al. 2010, Milanin et al. 2010, Carriero et al. 2013).

The four following species were associated with Brycon hilarii (Valenciennes) in Brazilian Pantanal wetlands: Myxobolus oliveirai Milanin, Eiras, Arana, Maia, Alves, Silva, Carriero, Ceccarelli et Adriano, 2010 and Myxobolus brycon Azevedo, Casal, Marques, Silva et Matos, 2011, which are parasites of gill filaments; Myxobolus umidus Carriero, Adriano, Silva, Ceccarelli et Maia, 2013, a parasite of the spleen; and Myxobolus piraputangae Carriero,
Adriano, Silva, Ceccarelli et Maia, 2013, a parasite of the kidney (Milanin et al. 2010, Azevedo et al. 2011, Carriero et al. 2013).

Brycon orthotaenia Günther, popularly known as 'matrinxã', is endemic to the river São Francisco basin in the southeast/northeast of Brazil, and is among the native species with a high risk of extinction (Godinho and Godinho 1994). This species has omnivorous feeding habits, can reach up to $7 \mathrm{~kg}$ in body weight and has great potential in regional aquaculture and fisheries (Sato et al. 2003, MPA 2012).

The aim of the present study was to describe, based on morphology, ultrastructure and sequencing of the $18 \mathrm{~S}$ rRNA gene, a new Myxobolus species that infects the gill filaments of B. orthotaenia caught in the River São Francisco in the state of Minas Gerais, Brazil.

\section{MATERIALS AND METHODS}

Thirty-nine specimens of Brycon orthotaenia were collected

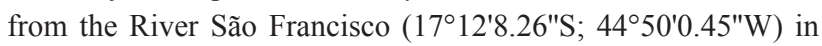
the municipality of Pirapora, state of Minas Gerais, Brazil. Sam- 
ples were collected in July $2010(n=5)$, July $(n=5)$ and December $2011(n=12)$, December of $2012(n=12)$ and December $2013(n=5)$. After capture, the fish were immediately transported alive to a nearby field laboratory, where they were euthanised by a benzocaine overdose. The methodology of the present study was approved by the ethics research committee of the State University of Campinas under protocol number 2334-1, in accordance with Brazilian law (Federal Law No. 11.794, dated 8 October 2008 and Federal Decree No. 6899, dated 15 July 2009).

Plasmodia with mature spores were examined in fresh mounts with a light microscope. The morphological characterisation of the spores was based on mature spores obtained from three different host specimens. Measurements were taken from 34 spores using a computer equipped with Axivision 4.1 image capture software, coupled to an Axioplan 2 Zeiss Microscope. The dimensions of the spores were expressed as range with (mean \pm standard deviation), all in $\mu \mathrm{m}$. Smears containing free spores were air-dried and stained with Giemsa solution and mounted in a low-viscosity mounting medium (Cytoseal ${ }^{\mathrm{TM}}$, Hatfield, PA, USA) on permanent slides for their deposition in the museum. For histological analysis, fragments of infected organs were fixed in $10 \%$ buffered formalin and embedded in paraffin. Serial sections with a thickness of $4 \mu \mathrm{m}$ were stained with hematoxylin-eosin.

For transmission electron microscopy, the plasmodia were fixed in cold $\left(4^{\circ} \mathrm{C}\right) 2.5 \%$ glutaraldehyde and $0.1 \mathrm{M}$ sodium cacodylate buffer ( $\mathrm{pH} 7.4$ ) for $12 \mathrm{~h}$, washed in a glucose-saline solution for $2 \mathrm{~h}$ and post-fixed in $\mathrm{OsO}_{4}$ After dehydration using an acetone series, the material was embedded in EMbed 812 resin. Semithin sections were stained with toluidine blue solution and examined by light microscopy. Ultrathin sections, double stained with uranyl acetate and lead citrate, were examined in an LEO 906 electron microscope at $60 \mathrm{kV}$. For sequencing, the plasmodia were removed from the host tissue and fixed in ethanol $100 \%$. The plasmodium content was collected in a $1.5-\mathrm{ml}$ microcentrifuge tube and the DNA was extracted using the DNeasy ${ }^{\circledR}$ Blood \& Tissue kit (Qiagen, Valencia, CA, USA), following the manufacturer's instructions. The product was quantified in a NanoDrop 2000 spectrophotometer (Thermo Scientific, Wilmington, USA) at $260 \mathrm{~nm}$.

The polymerase chain reaction (PCR) was carried out using a final volume of $25 \mu 1$, which contained $10-50 \mathrm{ng}$ of extracted DNA, $1 \times$ Taq DNA polymerase buffer, $0.2 \mathrm{mmol}$ of dNTP, $1.5 \mathrm{mmol}$ of $\mathrm{MgCl}_{2}, 0.2 \mathrm{pmol}$ of each primer, $0.25 \mu 1$ (1.25 U) of Taq DNA polymerase (all reagents from Invitrogen by Life Technologies, Carlsbad, CA, USA) and ultrapure (MilliQ) water in an Eppendorf AG 22331 Hamburg Thermocycler (Eppendorf, Hamburg, Germany). The 18S rRNA gene was amplified with the primer pairs ERIB1 (Barta et al. 1997) - ACT1r (Hallett and Diamant 2001) and Myxgen4F (Diamant et al. 2004) - ERIB10 (Barta et al. 1997), which amplified two fragments of approximately $1000 \mathrm{bp}$ and $1200 \mathrm{bp}$, respectively. An initial denaturation stage at $95^{\circ} \mathrm{C}$ for 5 min was followed by 35 cycles of denaturation at $95^{\circ} \mathrm{C}$ for $60 \mathrm{~s}$, annealing at $58^{\circ} \mathrm{C}$ for $60 \mathrm{~s}$, extension at $72^{\circ} \mathrm{C}$ for $120 \mathrm{~s}$, finishing with an extended elongation stage at $72{ }^{\circ} \mathrm{C}$ for $5 \mathrm{~min}$. PCR products were electrophoresed in $1.0 \%$ agarose gel, stained with GelRed ${ }^{\circledR}$ and analysed by an FLA-3000 (Fugi) scanner. The size of the amplicons was estimated by comparison with the $1 \mathrm{~kb}$ DNA Ladder (Invitrogen by Life Technologies, CA, USA).
The PCR products were purified with QIAquick ${ }^{\circledR}$ PCR Purification Kit (Qiagen) and then were sequenced using the same primer pairs that were used in the amplification stage, plus primers MC5 and MC3 (Molnár et al. 2002) with the BigDye ${ }^{\circledR}$ Terminator v3.1 Cycle Sequencing Kit (Applied Biosystems ${ }^{\mathrm{TM}}$, Foster City, CA, USA) in an ABI 3730 DNA sequencing analyser (Applied Biosystems ${ }^{\mathrm{TM}}$ Inc.). The sequence obtained was visualised, assembled and edited using BioEdit 7.1.3.0 software (Hall 1999). The ambiguous bases were clarified using corresponding ABI chromatograms. A standard nucleotide BLAST search was then conducted (Altschul et al. 1997). The BioEdit program (Hall 1999) was used to align the sequence obtained and to compare it with the sequences of species of Myxobolus and Henneguya Thélohan, 1892, recovered by BLAST, plus all sequences of South American species of these genera that did not appear in the BLAST search. Phylogenetic analyses were performed using the Maximum likelihood (ML) and Maximum parsimony (MP) methods.

In order to obtain the evolutionary model that best fit the sequences studied here, jModelTest analysis was performed using the Akaike information criteria (Posada 2008). ML analysis was performed with PhyML3.0 (Guindon et al. 2010) using the General Time Reversible substitution model and 4 gamma-distributed ration variations among sites. MP analysis was conducted with PAUP* 4.0b10 (Swofford 1998) using the heuristic search algorithm and tree bisection-reconnection (TBR) branch swapping. Myxidium anatidium Bartholomew, Atkinson, Hallett, Lowenstine, Garner, Gardiner, Rideou, Keel et Brown, 2011 (EF602629) and Myxidium hardella Garner, Bartholomew, Whipps, Nordhausen et Raiti, 2005 (AY688957) were used as an outgroup in this analysis. In both analyses, clade support was assessed by bootstrapping with 1000 replicates. The trees obtained were initially visualised with FigTree v1.3.1 (Rambaut 2008) and edited with Adobe Illustrator (Adobe Systems Inc., San Jose, USA). Only bootstrap values above 50 were considered to be wellsupported. The data of the family and/or order of host fish were obtained from Froese and Pauly (2013).

Distance analysis was performed to compare the new species with the most closely related species in the phylogenetic tree, using a p-distance model distance matrix for transitions and transversions in MEGA 5.0 (Tamura et al. 2011).

\section{RESULTS}

From total of 39 specimens of Brycon orthotaenia caught in the river São Francisco, the gill filaments of 3 $(7.69 \%)$ had been parasitised by an unknown species of Myxobolus, which is described below.

Whitish plasmodia, elongated in shape and measuring up to $5 \mathrm{~mm}$, were located in the gill filaments of $B$. orthotaenia. Histopathological analysis showed its development in the subepithelial connective tissue of the gill filaments. The development of the parasite led to compression of the adjacent connective and epithelial tissues and numerous granulocytic cells were observed at the infection site (Fig. 1A,B). The plasmodia exhibited asynchronous development, with mature spores in the central region and young sporogenous stages in the peripheral area (Fig. 1B).

Ultrastructure analysis revealed that the plasmodia were delimited by two membranes, which had numerous and 
extensive pinocytotic channels of approximately $5 \mu \mathrm{m}$ in length extending into the ectoplasm zone (Fig. 2A-D). The plasmodial wall exhibited abundant villi-like projections and a thin layer of granular material prevented direct contact between the plasmodial wall and the host cells of the adjacent connective tissue (Fig. 2A-C). Several mitochondria were observed in the ectoplasm. Early stages of sporogenesis and advanced spore developmental stages were noted below the ectoplasm, with sporoblasts containing two spores (Fig. 2A,B). Sporoplasms were binucleate and had small and scarce sporoplasmosomes (Fig. 2D).

\section{Myxobolus filamentum sp. $\mathrm{n}$.}

Figs. 1-3

ZooBank number for species:

urn:1sid:zoobank.org:act:29E5CA08-251D-

40B2-84AD-1FD90EAB83D0

Description. Mature spores pear-shaped in frontal view, measuring 7.5-9.7 (9.0 \pm 0.3$)$ in length, 5.2-7.3 (6.2 \pm 0.4$)$ in width and 4.8-5.7 (5.3 \pm 0.3$)$ in thickness (Figs. 1C, 3; Table 1). In lateral view, spores biconvex, with symmetrical valves. Polar capsules elongated and equal in size, measuring 3.8-5.5 $(4.7 \pm 0.3)$ in length and $1.3-2.2(1.7 \pm 0.1)$ in width. Polar capsule occupies about half of spore (Figs. 1C, 3). Polar filaments with 10-11 coils arranged perpendicularly to longitudinal axis of polar capsule (Figs. 2D, 3).

Type host: Brycon orthotaenia Günther (Characiformes: Bryconidae), 37-42 cm (39 $\pm 4 \mathrm{~cm})$.

Type locality: River São Francisco, municipality of Pirapora $\left(17^{\circ} 12^{\prime} 8.26^{\prime \prime} \mathrm{S} ; 44^{\circ} 50^{\prime} 0.45^{\prime \prime} \mathrm{W}\right)$, Minas Gerais state, Brazil. The type specimens of Myxobolus filamentum sp. n. was collected in December 2013.

Site of infection: Gill filament.

Prevalence: 3 of 39 specimes, i.e. $8 \%$, infected.

Specimens deposited: One slide containing spores fixed with methanol, stained with Giemsa and mounted in a lowviscosity mounting medium, deposited in the collection of the Museum of Zoology, Institute of Biology, Universidade Estadual de Campinas, São Paulo, Brazil (Accession No. ZUEC Myx 46).

DNA s e que n c e: 18S rRNA sequence deposited in the GenBank database under accession number KJ849240.

Etymology: The specific name refers to the infection site of the parasite, gill filaments, given that filamentum in Latin means filament.

Remarks. Myxobolus filamentum sp. n. was compared with all species of Myxobolus that have been described from South American freshwater fish and other continents (Eiras et al. 2005, 2014). So far, no species of myxosporean has been described from $B$. orthotaenia. Nevertheless, M. oliveirai, M. brycon, M. piraputangae and M. umidus have been reported from the congener $B$. hilarii. However, the spores of these four species differ morphometrically in some aspects from M. filamentum (Table 1), although $M$. oliveirai is the one that most resembles the species described herein, with both exhibiting a lightly-tapered anterior end and pear-shaped spores from the frontal view. Al-

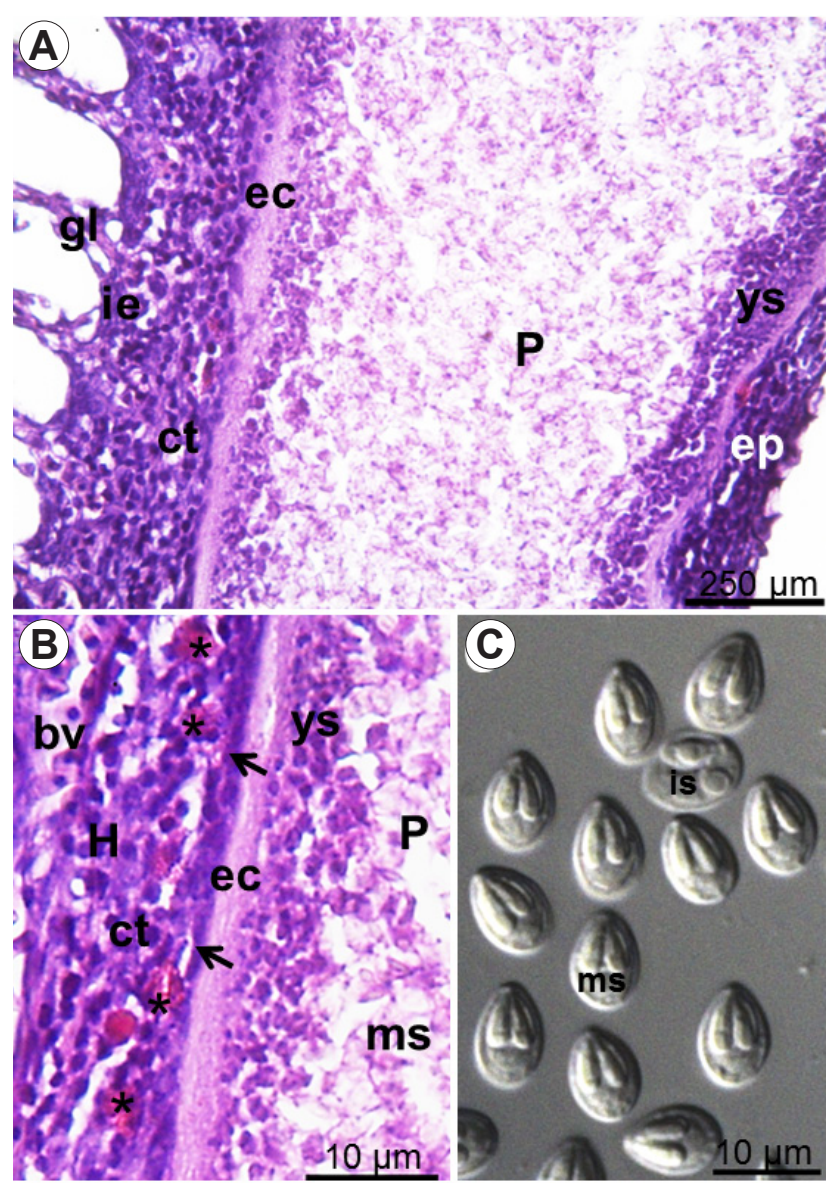

Fig. 1. Photomicrograph of Myxobolus filamentum sp. n. from Brycon orthotaenia. A - histological sections of gill filaments; B - amplified area of B showing host-parasite interface (arrows - compression of the adjacent connective tissue; asterisks - numerous granulocytic cells; $\mathbf{C}$ - mature (ms) and immature (is) spores observed with differential interference contrast (DIC) optics. Abbreviations: bv - blood vessel; ct - connective tissue; ec - ectoplasm; ep - epithelium; gl - gill lamellae; $\mathrm{H}$ - host; ie - interlamellar epithelium; ms - mature spores; $\mathrm{P}$ - plasmodium; ys - young sporogenous stages

though both species infect gill filaments of fish of the same genus (M. filamentum infects B. orthotaenia and M. oliveirai infects $B$. hilarii), these fish species occur in separated watersheds (B. orthotaenia in the São Francisco basin and $B$. hilarii in the Paraguay basin). Genetically, M. oliveirai was also the species that exhibited the smallest divergence to $M$. filamentum, although this divergence (4.5\%) was considered high enough to discriminate the two species.

Among the species of Myxobolus from bryconids of other genera, spores of Myxobolus pantanalis Carriero, Adriano, Silva, Ceccarelli et Maia, 2013, a parasite of Salminus brasiliensis (Cuvier), exhibit more morphometric resemblance to the species described herein, with a total spore length of $9.3 \mu \mathrm{m}$ for $M$. pantanalis and $9.0 \mu \mathrm{m}$ for M. filamentum, and a total body width of $6.5 \mu \mathrm{m}$ for M. pantanalis and $6.2 \mu \mathrm{m}$ for M. filamentum. However, M. pantanalis possesses oval spores from the frontal view and polar filaments with 4-5 turns versus 10-11 turns in M. filamentum. Furthermore, the genetic divergence between these two species was $12.8 \%$ (see below), which was also considered 


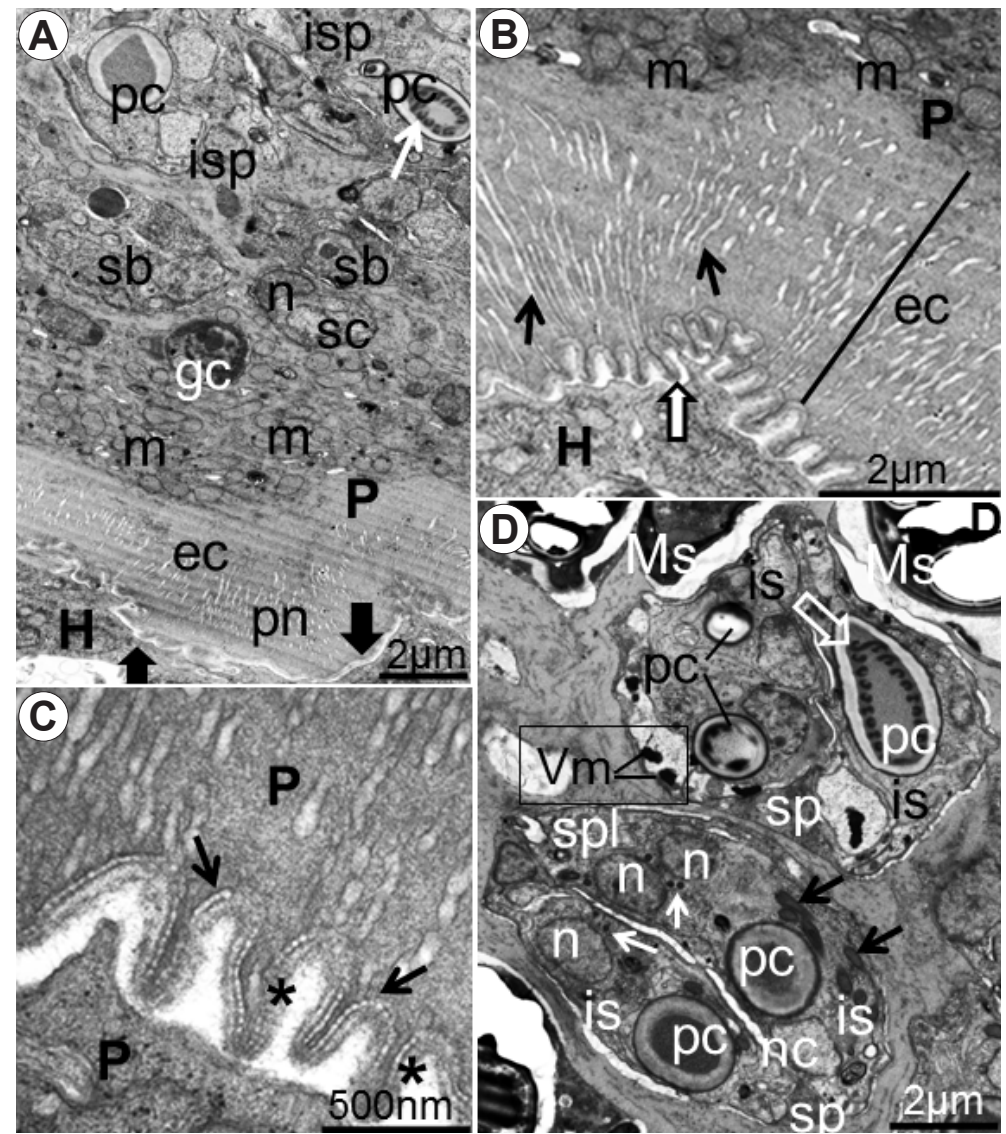

Fig. 2. Electron micrographs of plasmodia of Myxobolus filamentum sp. n. from gill filaments of Brycon orthotaenia. A - Numerous pinocytic channels (pn) linking the ectoplasm (ec) to the plasmodial wall (large black arrows). Numerous mitochondria (m), generative cells $(\mathrm{gc})$, young sporoblasts ( $\mathrm{sb}$ ) containing sporogenous cells $(\mathrm{sc})$ and their nuclei (n). See immature spores (isp) with polar capsules (pc) in the innermost layer, in some cases containing polar filaments (white arrow). B - host parasite interface showing abundant villilike projections of the plasmodial wall (large arrow), wide ectoplasm (ec) containing numerous and long pinocytic channels (thin arrows) and mitochondria (m). C - magnified part of B showing a layer of granular material (asterisks) surrounding the plasmodial wall composed by two membranes (black arrows). D - disporic sporoblasts (sp) sections containing immature spores (is) with polar capsules (pc) containing internalised (empty arrow) or still externalised polar filament (thin black arrow), sporoplasm (spl) with two nuclei (n) and few and small sporoplasmosomes (thin white arrow). Remaining abbreviations: $\mathrm{H}$ - host; $\mathrm{P}$ - plasmodium; Vm - valve-forming material; Ms - mature spores.

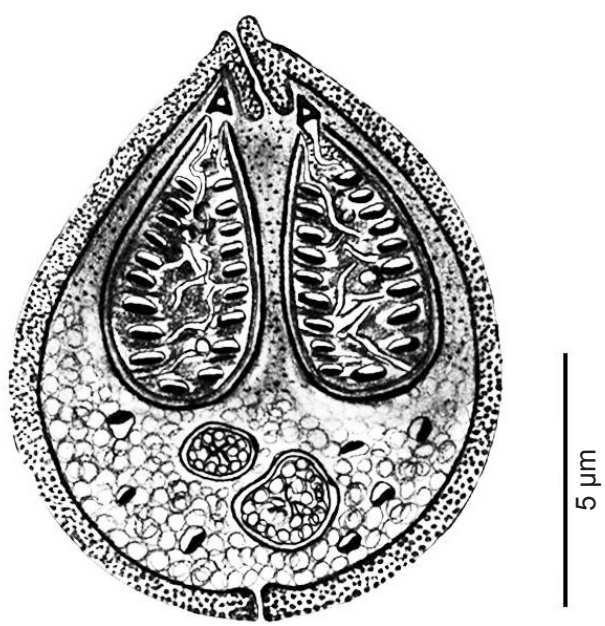

Fig. 3. Schematic representation of the mature spore of Myxobolus filamentum sp. n. infecting gill filament of Brycon orthotaenia in Brazil. high enough to distinguish the two species. With regards to other species of Myxobolus from freshwater fish in South American or other continents, M. filamentum differs in at least one of the morphometric/morphological characteristics, such as the shape and size of the plasmodia, the shape and size of the spores, the number of polar coils, the host and the site of infection (Eiras et al. 2005, 2014). Therefore, based on all of the evidence above, we propose that the species studied herein is a new species of Myxobolus.

Molecular data: Sequencing of the 18S rRNA gene of $M$. filamentum resulted in a partial sequence of $1885 \mathrm{bp}$. The most similar sequence to the species described here in according to BLAST was M. oliveirai (HM754633).

Maximum likelihood and Maximum parsimony phylogenetic trees showed species of Myxobolus/Henneguya clustering in two distinct clades. The smallest clade (A) was a cluster of parasites of characiform fishes (families Serrasalmidae and Bryconidae), all from South America. Clade B is further divided to form two clades: a small clade (B1), composed of Myxobolus species from salmonids, with Myxobolus cordeiroi Adriano, Arana, Alves, Silva, 
Table 1. Comparison data of Myxobolus filamentum sp. n. with other species of Myxobolus from bryconid fish.

\begin{tabular}{|c|c|c|c|c|c|c|c|c|c|c|}
\hline Species of Myxobolus & $\begin{array}{l}\text { Spore } \\
\text { length }\end{array}$ & $\begin{array}{l}\text { Spore } \\
\text { width }\end{array}$ & Thickness & LPC & WPC & $\mathrm{NCF}$ & $\begin{array}{l}\text { Site of } \\
\text { infection }\end{array}$ & Host & Locality & Source \\
\hline M. filamentum sp. n. & $\begin{array}{c}7.4-9.7 \\
(9.0 \pm 0.3)\end{array}$ & $\begin{array}{c}5.1-7.3 \\
(6.2 \pm 0.4)\end{array}$ & $\begin{array}{c}4.8-5.7 \\
(5.3 \pm 0.3)\end{array}$ & $\begin{array}{c}3.7-5.4 \\
(4.7 \pm 0.3)\end{array}$ & $\begin{array}{c}1.2-2.2 \\
(1.7 \pm 0.1)\end{array}$ & 10 & $\begin{array}{l}\text { gill } \\
\text { filaments }\end{array}$ & $\begin{array}{l}\text { Brycon } \\
\text { orthotaenia } \\
\text { Günther }\end{array}$ & $\begin{array}{l}\text { River São } \\
\text { Francisco, } \\
\text { Brazil }\end{array}$ & Present study \\
\hline $\begin{array}{l}\text { M. aureus } \\
\text { Carriero, Adriano, Silva, } \\
\text { Ceccarelli et Maia, } 2013\end{array}$ & $12.6 \pm 0.5$ & $8.3 \pm 0.3$ & $5.5 \pm 0.3$ & $5.7 \pm 0.3$ & $2.9 \pm 0.2$ & $7-8$ & liver & $\begin{array}{l}\text { Salminus } \\
\text { brasiliensis } \\
\text { (Cuvier) }\end{array}$ & PW, Brazil & Carrieiro et al. 2013 \\
\hline $\begin{array}{l}\text { M. brycon } \\
\text { Azevedo, Casal, } \\
\text { Marques, Silva et Matos, } \\
2011\end{array}$ & $\begin{array}{c}6.9 \\
(6.5-7.2)\end{array}$ & $\begin{array}{c}4.2 \\
(3.9-4.8)\end{array}$ & $\begin{array}{c}2.5 \\
(1.9-2.8)\end{array}$ & $\begin{array}{c}4.2 \\
(3.8-4.7)\end{array}$ & $\begin{array}{c}1.9 \\
(1.7-2.5)\end{array}$ & $8-9$ & gills & $\begin{array}{l}\text { Brycon hilarii } \\
\text { (Valenciennes) }\end{array}$ & PW, Brazil & Azevedo et al. 2011 \\
\hline $\begin{array}{l}\text { M. macroplasmodialis } \\
\text { Molnár, Ranzani-Paiva, } \\
\text { Eiras et Rodrigues, } 1998\end{array}$ & $\begin{array}{l}10.5-12 \\
(11)\end{array}$ & $\begin{array}{l}8-9 \\
(8.5)\end{array}$ & $\begin{array}{l}5-5.5 \\
(5.2)\end{array}$ & $\begin{array}{c}4-5 \\
(4.5)\end{array}$ & $\begin{array}{l}2-3 \\
(2.8)\end{array}$ & 6 & $\begin{array}{l}\text { abdominal } \\
\text { cavity }\end{array}$ & $\begin{array}{l}\text { Salminus } \\
\text { brasiliensis }\end{array}$ & $\begin{array}{l}\text { River Mogi, } \\
\text { Brazil }\end{array}$ & Molnár et al. 1998 \\
\hline $\begin{array}{l}\text { M. oliveirai } \\
\text { Milanin, Eiras, Arana, } \\
\text { Maia, Alves, Silva, } \\
\text { Carriero, Ceccarelli et } \\
\text { Adriano, } 2010\end{array}$ & $11.2 \pm 0.4$ & $7.4 \pm 0.5$ & $4.6 \pm 0.6$ & $5.6 \pm 0.2$ & $2.3 \pm 0.2$ & $6-8$ & gills & Brycon hilarii & PW, Brazil & Milanin et al. 2010 \\
\hline $\begin{array}{l}\text { M. pantanalis } \\
\text { Carriero, Adriano, Silva, } \\
\text { Ceccarelli et Maia, } 2013\end{array}$ & $9.3 \pm 0.4$ & $6.5 \pm 0.4$ & $\mathrm{~N} / \mathrm{A}$ & $4.2 \pm 0.5$ & $2.0 \pm 0.1$ & $4-5$ & $\begin{array}{l}\text { gill } \\
\text { filaments }\end{array}$ & $\begin{array}{l}\text { Salminus } \\
\text { brasiliensis }\end{array}$ & PW, Brazil & Carrieiro et al. 2013 \\
\hline $\begin{array}{l}\text { M. paranensis } \\
\text { Bonetto et Pignalberi, } \\
1965\end{array}$ & $12-15$ & $7-8$ & $\mathrm{~N} / \mathrm{A}$ & $6-7$ & 2.5 & N/A & $\begin{array}{l}\text { testes, } \\
\text { ovary }\end{array}$ & $\begin{array}{l}\text { Salminus } \\
\text { brasiliensis }\end{array}$ & Argentina & $\begin{array}{l}\text { Bonetto and } \\
\text { Pignalberi } 1965\end{array}$ \\
\hline $\begin{array}{l}\text { M. piraputangae } \\
\text { Carriero, Adriano, Silva, } \\
\text { Ceccarelli et Maia, } 2013\end{array}$ & $10.1 \pm 0.5$ & $8.7 \pm 0.5$ & $6.7 \pm 0.3$ & $5.2 \pm 0.4$ & $3.0 \pm 0.3$ & $4-5$ & kidney & Brycon hilarii & PW, Brazil & Carrieiro et al. 2013 \\
\hline $\begin{array}{l}\text { M. salminus } \\
\text { Adriano, Arana, } \\
\text { Carriero, Naldoni, } \\
\text { Ceccarelli et Maia, } 2009\end{array}$ & $10.1 \pm 0.4$ & $6.1 \pm 0.4$ & $5.0 \pm 0.6$ & $4.6 \pm 0.2$ & $1.7 \pm 0.1$ & $7-8$ & gills & $\begin{array}{l}\text { Salminus } \\
\text { brasiliensis }\end{array}$ & PW, Brazil & Adriano et al. 2009 \\
\hline $\begin{array}{l}\text { M. umidus Carriero, } \\
\text { Adriano, Silva, } \\
\text { Ceccarelli et Maia, } 2013\end{array}$ & $13.5 \pm 0.7$ & $7.8 \pm 0.4$ & $7.7 \pm 0.1$ & $5.1 \pm 0.4$ & $2.7 \pm 0.3$ & $4-5$ & spleen & Brycon hilarii & PW, Brazil & Carrieiro et al. 2013 \\
\hline
\end{tabular}

LPC - length of polar capsules; N/A - no data; NCF - number of coils of polar filaments; PW - Pantanal wetland; WPC - width of polar capsules.

Ceccarelli, Silva et Maia, 2009, a parasite of siluriform pimelodids in South America, as a basal species, and a large clade (B2), composed of species of Myxobolus/Henneguya from several families/orders of fishes. In this large clade, $M$. filamentum clustered as a sister species of $M$. oliveirai in a subclade that also contained species from percids and esocids (Fig. 4). The p-distance analysis showed that $M$. oliveirai was the species with the closest genetic similarity to $M$. filamentum, with a similarity of $95.6 \%$.

\section{DISCUSSION}

The development of plasmodia of Myxobolus filamentum sp. n. caused compression of the adjacent connective and epithelial tissues, deforming the neighbouring structures, as previously recorded in Henneguya mystusia Salkar, 1985, Myxobolus diversicapsularis Slukhai 1966, and Henneguya pseudoplatystoma Naldoni, Arana, Maia, Ceccarelli, Tavares, Borges, Pozo et Adriano, 2009. Inflammatory infiltrate with numerous granulocytic cells was observed in adjacent areas of the plasmodia, although the fish did not exhibit signs of sickness. Inflammatory infiltrate, composed of a mixed population of granulocytes including neutrophils and cells that resembled eosinophils, has been observed in proliferative gill disease (PGD) caused by species of Henneguya in the pond-reared channel catfish Ictalurus punctatus Rafinesque in North America (Lovy et al. 2011).
Ultrastructural analysis revealed that the plasmodia were delimited by two membranes, similar to Myxobolus metynnis Casal, Matos et Azevedo, 2006, M. salminus and $M$. brycon, which exhibited numerous and extensive pinocytic channels extending into the wide ectoplasmic zone (Casal et al. 2006, Adriano et al. 2009, Azevedo et al. 2010). The plasmodial wall also exhibited abundant villilike projections, similar to those reported for infection of host with M. metynnis, increasing surface area of the parasite (Casal et al. 2006). There was also a thin layer of granular material preventing contact between the plasmodium and host cells of the adjacent tissues, as observed in host infected with Henneguya cuniculator Naldoni, Maia, Silva et Adriano, 2014 (see Naldoni et al. 2014). The plasmodia exhibited intense nutritional and metabolic activity, with numerous and extensive pinocytic channels in the ectoplasm, as well as a layer immediately below the ectoplasm with large numbers of mitochondria.

With regards to sporogenesis, this process followed the pattern of other species of Myxobolus, with the early stages of spore formation in the periphery of the plasmodium and more mature spores located centrally (Current et al. 1979, Casal et al. 1997, 2002, Adriano et al. 2006). Myxobolus filamentum is the first myxosporean species reported from Brycon orthotaenia, the fifth in fish of the genus Brycon Muller et Troschel and the ninth of bryconid fish (Azevedo et al. 2010, Carriero et al. 2013, Moreira et al. 2014). Of 


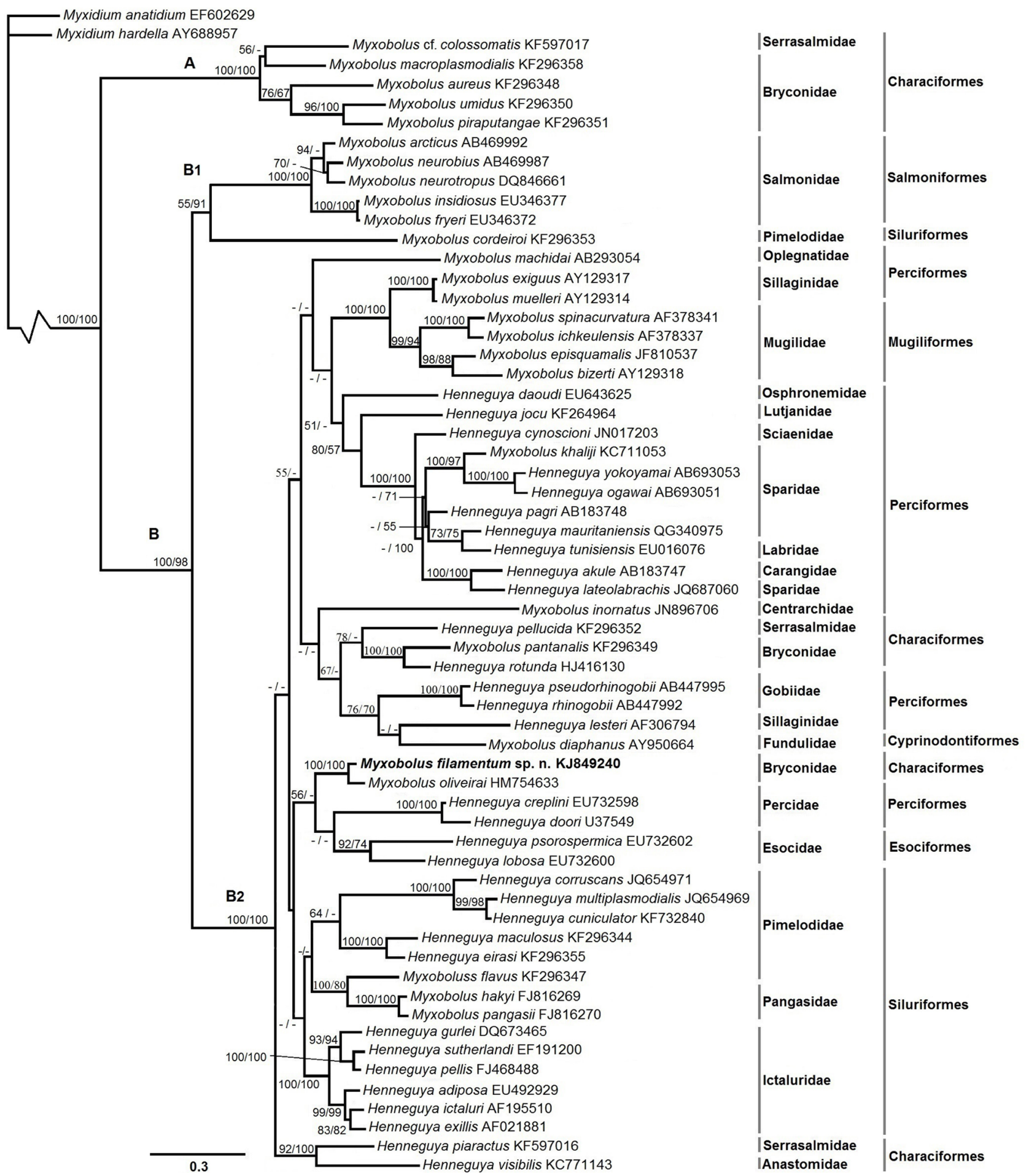

Fig. 4. Maximum likelihood phylogeny showing the position of Henneguya filamentum sp. n. parasite of Brycon orthotaenia compared to closely related Myxobolus/Henneguya species based on the partial 18S rDNA sequence. The bootstrap support values at branching points are listed as ML/MP for the nodes gaining more than $50 \%$ support.

these eight myxosporean species previously reported from bryconids, 18S rRNA sequences of seven species are available in GenBank and were used in the phylogenetic analyses of the present study.

Maximum likelihood and maximum parsimony analyses using the sequences of $M$. filamentum and 58 species of Henneguya and Myxobolus and two of species Myxidium retrieved from GenBank produced phylograms with a nearly identical topology. Species of Myxobolus and Henneguya from bryconids appeared in two distinct clades. In the clade A, which was composed exclusively by species of Myxobolus from characiform fish, parasites of bryconids were dominant. Inside this clade, Myxobolus cf. colossomatis Molnár et Békési, 1993 and Myxobolus macroplasmodialis Molnár, Ranzani-Paiva, Eiras et Rodrigues, 1998 clustered as sister species, yet with low bootstrap val- 
ues in ML analysis, whereas the former species appears as the basal species of the subclade composed by species of Myxobolus from bryconids in MP analysis (Fig. 4).

Clade B2 contained four other species, parasites of bryconids, which clustered in separate subclades. These were M. pantanalis from Brycon hilarii and Henneguya rotunda Moreira, Adriano, Silva, Ceccarelli et Maia, 2014 from Salminus brasiliensis, which clustered as sister species in a small subclade composed of parasites of characiform hosts, whereas M. filamentum appeared in another subclade as a sister species of $M$. oliveirai, a parasite of gill filaments of the congeneric $B$. hilarii. However, clade B2 presents several internal nodes with low bootstrap value. Nevertheless, despite the fact that some studies show the tendency of myxosporeans to group according to the phy- logenetic relationships of their fish hosts (Carriero et al. 2013, Shin et al. 2014), the results of the present study show polyphyletic clustering of the parasites of bryconids as well as of those from all characiform fish. This is in accordance with the results obtained by Moreira et al. (2014), who reported the polyphyletic clustering of the parasites of characiforms. In this context, future efforts aiming to describe new species of myxosporean parasites of characiform hosts, and their 18S rRNA sequencing, will be of great importance to clarify the evolutionary relationship of these parasites within the Myxozoa.

Acknowledgements. This study was supported by CNPq (project No. 472747/ 2012-6). J. Naldoni was supported by a FAPESP scholarship (project No. 2011/10738-1), S.A. Zatti and K.R.H. Capodifoglio were supported by CAPES scholarships.

\section{REFERENCES}

Adriano E.A., Arana S., Carriero M.M., Naldoni J., CecCARELli P.S., Maia A.A. 2009: Light, electron microscopy and histopathology of Myxobolus salminus n. sp., a parasite of Salminus brasiliensis from the Brazilian Pantanal. Vet. Parasitol. 165: 25-29.

Adriano E.A., Arana S., Cordeiro N.S. 2006: Myxobolus cuneus n. sp. (Myxosporea) infecting the connective tissue of Piaractus mesopotamicus (Pisces: Characidae) in Brazil: histopathology and ultrastructural. Parasite 13: 137-142.

Altschul S.F., Madden T.L., Schaffer A.A., Zhang J., Zhang Z., Miller W., Lipman D.J. 1997: Gapped BLASTn and PSI-BLAST: a new generation of protein database search programs. Nucl. Acids Res. 25: 3389-3402.

Azevedo C., Casal G., Matos P., Alves A., Matos E. 2011: Henneguya torpedo sp. nov. (Myxozoa), a parasite from the nervous system of the Amazonian teleost Brachyhypopomus pinnicaudatus (Hypopomidae). Dis. Aquat. Org. 93: 235-242.

Azevedo C., Marques D.K.S., Casal G., Amaral C.M.C., Silva E.V., Matos P., Matos E. 2010: Ultrastructural re-description of Henneguya piaractus (Myxozoa), a parasite of the freshwater fish Piaractus mesopotamicus (Teleostei, Characidae) from the Paraguai River, Brazil. Acta Protozool. 49: 115-120.

Barta J.R., Martin D.S., Liberator P.A., DashKevicz M., Anderson J.W., Feighner S.D., Elbrecht A., PerKinsbarrow A., Jenkins M.C., Danforth H.D., Ruff M.D.,Profousjuchelka H. 1997: Phylogenetic relationships among eight Eimeria species infecting domestic fowl inferred using complete small subunit ribosomal DNA sequences. J. Parasitol. 83: 262-271.

Bartholomew J.L., Atkinson S.D., Hallett S.L., LowenStine L.J., Garner M.M., Gardiner C.H.; Keel M.K.; BRown J.D. 2008: Myxozoan parasitism in waterfowl. Int. J. Parasitol. 38: 1199-1120.

Bonetto A.A., Pignalbergi C. 1965: Myxobolus paranensis (Protozoa, Myxosporidea) una nueva especie parasita del "Dorado" (Saminus maxillosus). Physis 69: 23-26.

Carriero M.M., Adriano E.A., Silva M.R.M., CeccaRelli P.A., Maia A.A.M. 2013: Molecular phylogeny of the Myxobolus and Henneguya genera with several new South American species. PLoS ONE 8: e73713.

Casal G., Matos E., Azevedo C. 1997: Some ultrastructural aspects of Henneguya striolata sp. nov. (Myxozoa: Myxosporea), a parasite of the Amazonian fish Serrasalmus striolatus. Parasitol. Res. 83: 93-95.

Casal G., Matos E., Azevedo C. 2002: Ultrastructural data on the spore of Myxobolus maculatus n. sp. (phylum Myxozoa), parasite from the Amazonian fish Metynnis maculatus (Teleostei). Dis. Aquat. Org. 51: 107-112.
Casal G., Matos E., Azevedo C. 2006: A new myxozoan parasite from the Amazonian fish Metynnis argenteus (Teleostei, Characidae): light and electron microscope observations. J. Parasitol. 92: 817-821.

Current W.L., Janovy J. JR., Knight S.A. 1979: Myxosoma funduli Kudo (Myxosporida) in Fundulus kansae: ultrastructure of the plasmodium wall and of sporogenesis. J. Protozool. 26: 574-583.

Diamant A., Whipps C.M., Kent M.L. 2004: A new species of Sphaeromyxa (Myxosporea: Sphaeromyxina: Sphaeromyxidae) in devil firefish, Pterois miles (Scorpaenidae), from the northern Red Sea: morphology, ultrastructure, and phylogeny. J. Parasitol. 90: 1434-1442.

Eiras J.C., Molnár K., Lu Y.S. 2005: Synopsis of the species of Myxobolus Bütschli, 1882 (Myxozoa: Myxosporea: Myxobolidae). Syst. Parasitol. 61: 1-46.

Eiras J.C., Zhang J., Molnár K. 2014: Synopsis of the species of Myxobolus Bütschli, 1882 (Myxozoa: Myxosporea: Myxobolidae) described between 2005 and 2013. Syst. Parasitol. 88: $11-36$

Froese R., Pauly D. (Eds.) 2013: FishBase. World Wide Web electronic publication, www.fishbase.org, 07/2014.

Godinho H.P., Godinho A.L. 1994: Fish communities in southeastern Brazilian river basins submitted to hydroelectric impoundments. Acta. Limnol. Bras. 5: 187-197.

Guindon S., Dufayard J.F., Lefort V., Anisimova M., HordiJK W., Gascuel O. 2010: New algorithms and methods to estimate maximum likelihood phylogenies: assessing the performance of PhyML 3.0. Syst. BIOL. 59: 307-321.

Hall T.A. 1999: BioEdit: a user-friendly biological sequence alignment editor and analysis program for Windows 95/98/NT. Nucl. Acids Symp. Ser. 41: 95-98.

Hallett S.L., Diamant A. 2001: Ultrastructure and smallsubunit ribosomal DNA sequence of Henneguya lesteri $\mathrm{n}$. $\mathrm{sp}$ (Myxosporea), a parasite of sand whiting Sillago analis (Sillaginidae) from the coast of Queensland, Australia. Dis. Aquat. Org. 46: $197-212$

Lovy J., Goodwin A.E., Speare D.J., Wadowska D.W., WRIGHT G.M. 2011: Histochemical and ultrastructural analysis of pathology and cell responses in gills of channel catfish affected with proliferative gill disease. Dis. Aquat. Org. 94: 125-134.

Milanin T., Eiras J.C., Arana S., Maia A.A.M., Alves A.L., Silva M.R.M., Carriero M.M., Ceccarelli P.S., Adriano E.A. 2010: Phylogeny, ultrastructure, histopathology and prevalence of Myxobolus oliveirai sp. nov., a parasite of Brycon hilarii (Characidae) in the Pantanal wetland, Brazil. Mem. Inst. Oswaldo Cruz 105: 762-769. 
Molnár K., Ranzani-Paiva M.J., Eiras J.C., Rodrigues E.L. 1998: Myxobolus macroplasmodialis sp. n. (Myxozoa: Myxosporea), a parasite of the abdominal cavity of the characid teleost, Salminus maxillosus, in Brazil. Acta Protozool. 37: 241-245.

Molnár K., Eszterbauer E., Székely C., Dán A., Harrach B. 2002: Morphological and molecular biological studies on intramuscular Myxobolus spp. of cyprinid fish. J. Fish Dis. 25: $643-652$.

Moreira G.S.A., Adriano E.A., Silva M.R.M., Ceccarelli P.S., MaiA A.A.M. 2014: The morphological and molecular characterization of Henneguya rotunda n. sp., a parasite of the gill arch and fins of Salminus brasiliensis from the Mogi Guaçu River, Brazil. Parasitol. Res. 113: 1703-1711.

MPA 2012: Ministry of Fisheries and Agriculture (Ministério da Pesca e Aqüicultura): Sporting freshwater fishes (Peixes esportivos de água doce). World Wide Web electronic publication, http://www.mpa.gov.br/index.php/topicos/33-amadora/1285peixe-matrinxã, $1 / 2014$

Naldoni J., Maia A.A.M., Silva M.R.M., Adriano E. 2014 Henneguya cuniculator sp. nov., a parasite of spotted sorubim Pseudoplatystoma corruscans in the São Francisco Basin, Brazil. Dis. Aquat. Org. 107: 211-221.
Posada D. 2008: jModelTest: phylogenetic model averaging. Mol. Biol. Evol. 25: 1253-1256.

Prunescu C.C., Prunescu P., Pucek Z., Lom J. 2007: The first finding of myxosporean development from plasmodia to spores in terrestrial mammals: Soricimyxum fegati gen. sp n. (Myxozoa) from Sorex araneus (Soricomorpha). Folia Parasitol. 54: $159-164$.

Rambaut. 2008: FigTree v1.1.1: Tree figure drawing tool. http:// tree.bio.ed.ac.uk/software/figtree/ (accessed 7/2014).

Sato Y., Fenerich-Verani., Godinho H.P. 2003: Reprodução induzida de peixes da bacia do São Francisco. In: H.P. Godinho and A.L. Godinho (Eds), Águas, Peixes e Pescadores do São Francisco das Minas Gerais. Belo Horizonte, PUC Minas, pp. 275-289.

Shin S.P., Nguyen V.G., Jeong J.M., Jun J.W., Kim J.H., Jan J.E., BAECK G.W., PARK S.C. 2014: The phylogenetic study on Thelohanellus species (Myxosporea) in relation to host specificity and infection site tropism. Mol. Phyl. Evol. 72: 31-34.

Swofford D.L. 1998: PAUP*. Phylogenetic Analysis Using Parsimony (*and Other Methods). Ver. 4. Sinauer Associates, Sunderland, MA.

Tamura K., Peterson D., Peterson N., Stecher G., Nei M., Kumar S. 2011: MEGA5: Molecular Evolutionary Genetics Analysis using maximum likelihood, evolutionary distance, and maximum parsimony methods. Mol. Biol. Evol. 28: 2731-2739. (Characiformes: Bryconidae) in Brazil. Folia Parasitol. 62: 014. 